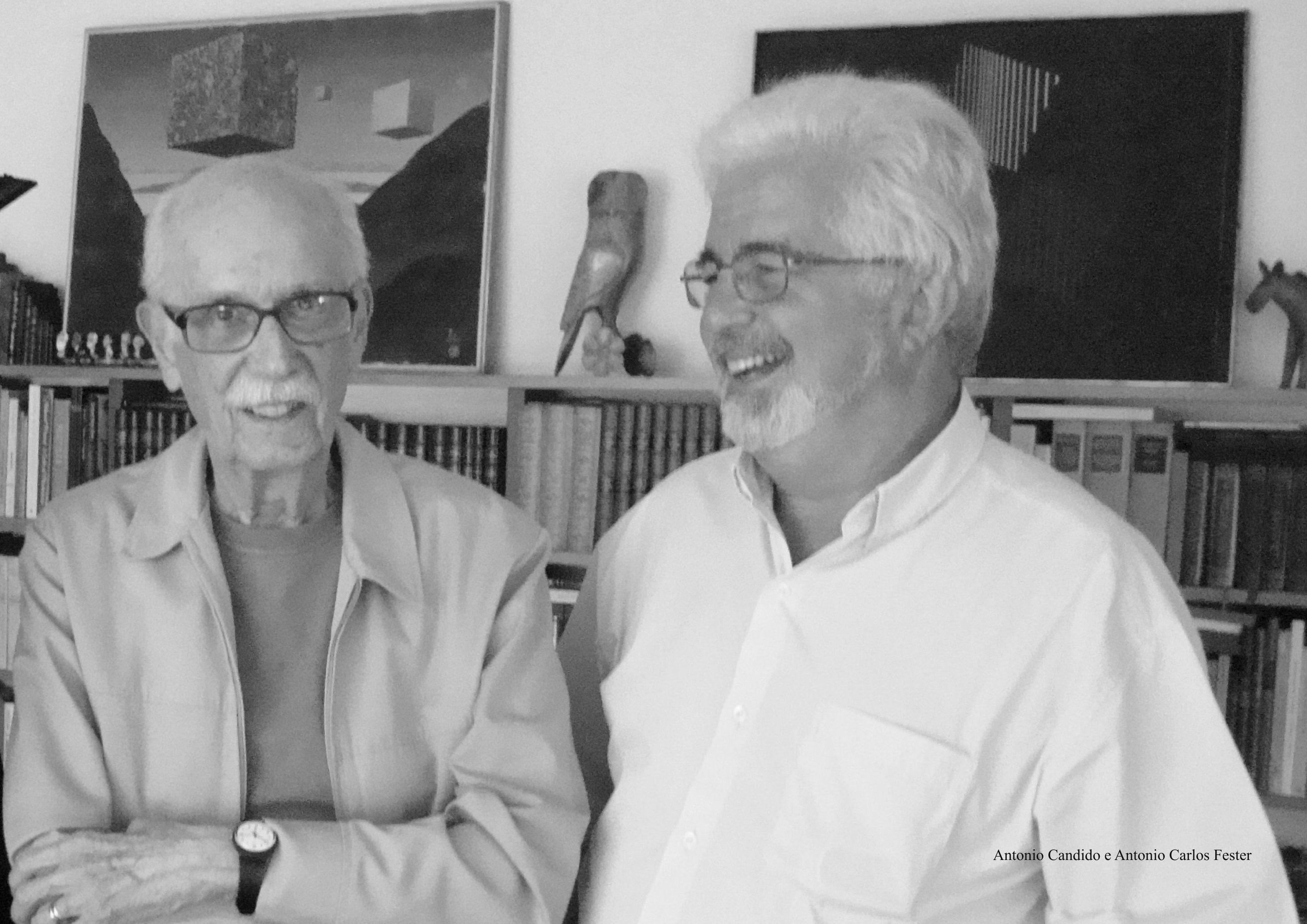




\title{
Antonio Candido, uma amizade
}

\author{
Antonio Carlos Fester*
}

\section{RESUMO}

Antonio Candido humanizador poderia ser outro título deste texto, escrito em função de sua palestra "O direito à literatura" e do conceito de humanização nela contido. Vendo, como ideias, conteúdos fundamentais para a educação em direitos humanos - cujo maior objetivo é a humanização - testemunho como muitos desses aspectos sempre estiveram presentes nos seus escritos e no modo de ser do Professor, tais como o senso da beleza, o humor apurado, a reflexão, o estudo, uma fina percepção da complexidade do mundo e dos seres, mas, especialmente, uma grande capacidade de ser amigo, tendo mantido algumas amizades que se fizeram históricas.

Palavras-chave: Direitos Humanos. Literatura. Humanização. Humor. Amizade.

Educador em Direitos Humanos, Escritor, Mestre em Letras pela Universidade de São Paulo (USP). 


\section{Antonio Candido, a friendship}

\section{ABSTRACT}

Antonio Candido humanizer could be another title of this text, written in function of his lecture: The right to Literature and the concept of humanization contained therein. His ideas and fundamental contents for Human Rights educationwhose greatest goal is humanization- testify how many of these aspects have always been present in his writings and in teacher's way of being, as well as his sense of beauty, his refined humor, his reflections, his studies, his fine perception of world and individual complexity, but especially his great capacity of being a friend, and maintaining some friendships that have become historical.

Keywords: Human Rights. Literature. Humanization. Humor. Friendship. 
Antonio Candido e eu sempre concordávamos que nossa maior riqueza eram as amizades. Um tesouro, um privilégio, ser amigo dele. É disto que vou tentar falar neste texto.

Por ocasião da outorga do título de Professor Emérito da USP a Antonio Candido, escrevi artigo publicado no jornal da União Brasileira de Escritores (UBE), que finalizei afirmando que, mais do que informar, o Professor formava. (FESTER, 1984, p. 4).

Em carta manuscrita, datada de 15 de outubro de 1984, o Professor me escreveu, agradecendo a nota

generosa e cordial. Além de comparecer, você fez mais esta gentileza, pela qual fico realmente agradecido. Tocaram-me de modo especial as palavras finais, contendo o que é mais grato a um professor: o testemunho caloroso e simpático de um ex-aluno de sua qualidade. Coisas como esta fazem a gente sentir-se justificado. (CANDIDO, 1984)

Antonio Candido sempre cultivou, até seu fim, o hábito de escrever cartas - mandava cartas, pelo correio, a pessoas como Adélia Bezerra de Menezes, ex-aluna e também amiga - que, como eu, mora a poucas quadras do último apartamento em que ele viveu, à rua Joaquim Eugênio de Lima.

Só agora me dou conta de que enviou a carta a mim no endereço da UBE, rua 24 de maio, 250, $13^{\circ}$ andar, colocando como remetente A. C. Mello e Souza, Rua Bryaxis, 11, o sobradinho que muitos de nós, seus alunos, visitávamos com o coração aos pulos, recebidos por ele e pela gentileza de dona Gilda.

Carta anterior, datada de 31 de janeiro de 1983, na qual me cumprimentou pelo casamento, foi dirigida à minha casa: 
Com duas netas para tomar conta, sem empregada, não era possível ir à recepção, já que a hora da cerimônia religiosa estava passada, estávamos amarrados ao ofício de avós...(...) A sua estima, como sabe, é plenamente correspondida, e nós fazemos os melhores e mais sinceros votos pela felicidade de vocês dois.

Quando começou essa amizade plenamente correspondida? Não sei, sei apenas que foi na década de 70, quando fui seu aluno na graduação em Letras. Tampouco me lembro da primeira vez que o vi ou das primeiras aulas. Mas Orôncio Vaz de Arruda, vizinho e amigo, diretor cultural da Fundação Oscar Americano, nascido em Araraquara, sobrinho bisneto de Pio Lourenço Corrêa, mandou algum recado para ele. Nunca é demais lembrar que foi na propriedade de Pio Corrêa, em Araraquara, que Macunaíma foi escrito, e que dona Gilda, nascida em Araraquara, saiu da casa de Mário de Andrade, seu primo, onde morava em São Paulo com a família dele, para casar-se.

Antonio Candido, por sua vez, ficou entusiasmado pelo meu parentesco, longínquo na árvore genealógica, mas próximo pelo afeto, com a família Papaterra Limongi. Contava e recontava o concurso a que assistiu, na década de 30, para a Cadeira, salvo engano, de Direito do Trabalho na USP, na qual João Papaterra Limongi (que considero como avô) foi vencido por Antonio Ferreira Cesarino Júnior, pai de outro grande amigo meu, o xará Antonio Carlos Cesarino, um dos introdutores do Psicodrama no Brasil.

Essas pessoas em comum nos aproximaram, sempre deram muito assunto, e levaram-me bem depressa a frequentar a casa da rua Bryaxis, da qual guardei a seguinte anedota. Chego, e Antonio Candido está em pé na sala, dicionário na mão, escrevendo um cartão para alguém: "Você já pensou, Antonio 
Carlos, se Antonio Candido erra?". Seu bom humor e as risadas frequentes foram outros dos laços que alimentamos.

Não resisto a uma indiscrição. Dona Gilda saiu, e ele, muito faceiro, me diz: "Agora podemos falar do PT". Estranhei. Ele acrescentou: "Gilda é tucana. Casamento que dá certo é aquele em que se sabe que nem tudo é para ser dito.”. Casou-se sete dias antes do meu nascimento e dizia que o envelhecia não o fato de estar com mais de noventa, mas que ex-alunos como eu estivéssemos com mais de setenta.

Outra piada ele disse na viagem em que os levamos, Helenice e eu, para a festa dos setenta anos de Margarida Genevois, no sítio dela em Barão Geraldo, Campinas, em 1993. "Se um dia, eu ficar caduco, eu me mato. E você não precisa fazer esta cara, porque não saberei que estou caduco e então não me mato".

Mais uma e tentarei ficar sério. Encontrava-se com as duas filhas do Papaterra em concertos no Municipal, na década de 30. Quando the disse que uma delas tornara-se freira, ele achou natural, pois ela sempre baixava os olhos. "Nunca baixei os olhos perante homem nenhum", me disse, indignada, minha amada prima Biloca, quando contei a ela o comentário. "Tímida era a Conceição", mãe dos primos que têm sido verdadeiros irmãos para mim. E Antonio Candido deu uma de suas gostosas gargalhadas ao saber da reação ao seu comentário.

Freiras, padres, religião, Jesus, esse ateu conhecia como poucos, o que me levou a dizer certa feita ao Cardeal Odilo Scherer: "Tomara todos os católicos fossem ateus como Antonio Candido". Pois esse Professor foi um justo, justo no sentido mais evangélico da palavra.

Em 22 de julho de 1998, o jornal O São Paulo, da Arquidiocese, publicou artigo meu intitulado "Antonio Candido, 80 anos de humanização". Escrevi, finalizando: 
Cita-me Maritain que, em resposta a Jean Cocteau, disse que santos são os que conhecem verdadeiramente o mal e o ultrapassam. Os estóicos, agora não sei se para Jacques Maritain ou Antonio Candido, seriam os reprimidos, que ignoram o mal. Lembrei-lhe D. Helder, que diz que a santidade consiste em cair a cada dia e levantar-se sempre. Depois, emocionado, Antonio Candido contou-me de uma prima carmelita que não deseja ir para um céu em que ele não esteja. Como ela, eu também não quero, professor, ir para um lugar onde o senhor não esteja. Na dúvida, vamos ficando por aqui, para que eu possa escrever mais, nos seus noventa anos.

Dez anos antes, frei Betto indicou-me para trabalhar na Comissão Justiça e Paz, da qual depois me tornei membro. O Professor ficou contente, eu estaria entre as melhores pessoas da cidade, livre das competições e tensões tão comuns na USP. Ledo engano. $\mathrm{Na}$ primeira reunião a que compareci e disse o que me deu na telha, já desagradei a algumas pessoas, levando Alfedo Bosi a me chamar a um canto e me aconselhar a tomar cuidado antes de falar, pois "a vaidade humana é infinita". Ríamos sempre sobre isso, o Professor e eu, riamos da vaidade humana, riamos de nós mesmos, "você acha que alguém vai se lembrar de mim daqui a uns anos ? Não saberão nem quem foi Antonio Candido".

Foi membro da Comissão, por uns dois anos, estava lá em 1980, quando Dalmo Dallari foi sequestrado e surrado, em uma tentativa de impedi-lo de encontrar-se com o Papa em visita ao Brasil:

Eu estava em casa quando recebi um telefonema do Carlos Guilherme Mota, contando que Dalmo tinha sido agredido e tudo isto. Fui imediatamente para a casa do Dalmo. Vi a camisa dele ensanguentada, as filhas dele. E fiquei até alta madrugada. Carlos Guilherme estava lá o tempo todo. Nunca me esqueço. [...] Bateram no Dalmo 
perto da minha casa, perto da marginal, espetaram ele com uma espécie de punhal. (FESTER, 2005, p. 146).

Mesmo ferido, Dallari conseguiu ir à missa campal do Papa João Paulo II, televisionada para o mundo inteiro, sua simples presença provocando uma denúncia viva das arbitrariedades da ditadura civico-militar pós 1964. Lembrava com carinho dos companheiros José Carlos Dias, Ivi Nogueira Nico, Iris Ariê. Diz Antonio Candido:

Um dia, o Flávio Di Giorgi estava lá e eu também, o José Gregori presidindo uma reunião e nós conversando. Eu disse que a "santidade era uma aspiração profunda de todo homem, crente ou não-crente, um ponto ideal a que cada homem se propunha, não para si, porque cada um sabe bem de suas fraquezas, mas a existência do santo nos realiza de certa maneira. Chamo de santidade o esforço máximo que a pessoa faz para se esquecer ao máximo, e fazer, ao máximo, coisas que sejam em benefício dos outros". De repente, o José Gregori olhou para nós dois e disse: "Você e o Flávio são os nossos teólogos”. Foi uma gargalhada só. (FESTER, 2005, p. 159).

Saiu da Comissão por causa do celibato (um problema com um padre flagrado em um motel), com os seguintes comentários:

Eu acho que na Igreja do século XX não tem mais sentido. E um dia fiz o seguinte raciocínio: "Como é que estou numa Comissão de Direitos Humanos ligada a uma Arquidiocese tão esclarecida como a de São Paulo, com dom Paulo à frente, como é que uma Comissão de Direitos Humanos pertence a uma Igreja que nega aos seus sacerdotes, aos seus ministros, um direito fundamental que a satisfação da sua afetividade, um direito que permite a propagação da espécie e a continuidade do gênero humano? Isto para mim é decisivo, não posso continuar. (FESTER, 2005, p. 160). 
Dias antes de dom Paulo completar 90 anos, em setembro de 2011, fomos levados de carro por frei Betto, para cumprimentálo. Irmã Terezinha de Brito bateu a foto de nós quatro, da qual tanto me orgulho e tenho sobre o piano. A reverência do Professor pelo Cardeal sempre me emocionou. E dois fatos marcaram Antonio Candido nesse dia. O Cardeal, em um lapso momentâneo, mas ao qual estava ficando sujeito, perguntou qual era sua ocupação. Respondeu que era professor. Isso o desgostou. Disse-me que não voltaria a visitar o Cardeal para não testemunhar a decadência de homem tão querido. $\mathrm{O}$ outro fato, foi Betto ter parado, na volta, para auxiliar uma senhora com o carro quebrado. Sempre se referiu, depois, a esse ato, pelo que teve de gratuidade e pronta disponibilidade, características do nosso querido amigo comum.

Por indicação de Marco Antonio Rodrigues Barbosa e Margarida Genevois, idealizadores e gestores do Projeto Educação em Direitos Humanos da Comissão Justiça e Paz, solicitei ao Professor uma palestra dentro de um Ciclo sobre "Direitos Humanos e...", realizado no salão nobre da Faculdade de Direito do largo de São Francisco.

Antonio Candido pronunciou sua palestra em 28 de abril de 1988, o que considerou um digno fecho de sua carreira, o grande texto produzido na idade da maturidade. Era sua humildade que o fazia pensar assim. Produziu textos notáveis sempre, mais curtos talvez, muitos de circunstâncias, prefácios como os das cartas entre Mário e Pio Lourenço ou de Mário de Alencar com Machado de Assis. Um texto muito me toca, póstumo, que sua neta Laura Escorel publicou e no qual afirma que tudo passará, mas os livros, estes ficarão.

O contexto em que se deu sua palestra sobre direitos humanos e literatura, em um momento em que se propugnavam 
que as barbaridades do movimento de 64 não se repetissem, pode ter colaborado para a repercussão e importância de sua fala, mas o mérito está mesmo é no seu conteúdo, pelo que acrescentou à reflexão não só dos direitos humanos, mas da vida em si mesma. O maior mérito, parece-me, está na afirmação de que todos, todos sem exceção, têm direito à literatura, ou mais, têm direito ao acesso à cultura em todas as suas formas, considerando-se cultura no seu sentido mais amplo, todos têm direitos à vida em plenitude.

Quando publicada em livro, no ano seguinte, resolveu um conflito que se instalara na Secretaria Municipal da Educação administrada à época por Paulo Freire, que comprara para cada escola municipal um exemplar de Grande Sertão: Veredas, de Guimarães Rosa. Alguns professores estavam indignados em como um "livro tão difícil" poderia ser acessado por alunos vindos de família com baixa ou nenhuma escolaridade. Mas disse o Mestre:

Acabei de focalizar a relação da literatura com os direitos humanos de dois ângulos diferentes. Primeiro, verifiquei que a literatura corresponde a uma necessidade universal que deve ser satisfeita sob pena de mutilar a personalidade, porque pelo fato de dar forma aos sentimentos e à visão de mundo ela nos organiza, nos liberta do caos e portanto nos humaniza. Negar a fruição da literatura é mutilar a nossa humanidade. (CANDIDO, 1995, p. 256).

Antonio Candido é enfático. Em um só parágrafo ele fala que negar o acesso à literatura implica em mutilar a personalidade, mutilar a nossa humanidade.

A palestra teve o título de "Direitos Humanos e Literatura" e como tal foi publicada em Direitos Humanos e... (Medo, 
Aids, Anistia Internacional, Estado, Literatura), pela Editora Brasiliense, em 1989, com prefácio do Cardeal Arns. Efetuei a transcrição, que depois contou com edição feita pelo autor. Posteriormente, o texto teve seu nome alterado, creio que por ele mesmo, ao inclú́-lo na terceira edição revista e ampliada de Vários Escritos (CANDIDO, 1995), para "O direito à literatura" e é com esse título que fica para a posteridade.

Pronunciada hoje, essa palestra teria o tom otimista que Candido lhe deu? Irenísia Torres de Oliveira, em um denso e ótimo ensaio sobre ela, indiretamente responde:

Hoje, quase trinta anos depois da publicação de "o direito à literatura", o cenário das exigências de dessegregação parece ter mudado. As últimas décadas viram surgir uma imensa quantidade e variedade de coletivos culturais... [...] O esforço de dessegregação cultural e de democracia atualmente seria mais, me parece, o de abrir os canais a professores, estudiosos, escritores e fruidores de cultura erudita, não necessariamente das classes dominantes, para o influxo desse rico manancial de práticas culturais. (FONSECA; SCHWARZ, 2018, p. 273).

Nas nossas conversas, antes e depois dessa fala e desse texto, ficou claro para mim que a finalidade dos direitos humanos é a humanização, das pessoas, das sociedades, do mundo. Em 1972, Candido já falara que a literatura não corrompe e não edifica, "mas trazendo em si o que chamamos o bem e o que chamamos o mal, humaniza em sentido profundo, porque faz viver" (CANDIDO, 2002, p. 85).

Trocando minhas aulas de literatura nas Faculdades Metropolitanas Unidas pelo Projeto Educação em Direitos Humanos, passei a incluir, em minhas atividades, cursos ou palestras pelo país, seu entendimento de que humanização é: 
[...] o processo que confirma no homem aqueles traços que reputamos essenciais, como o exercício da reflexão, a aquisição do saber, a boa disposição para com o próximo, o afinamento das emoções, a capacidade de penetrar nos problemas da vida, o senso da beleza, a percepção da complexidade do mundo e dos seres, o cultivo do humor. (CANDIDO, 1995, p. 249).

O humor, que sempre cultivamos na nossa convivência, como relatei nos "causos" dos inícios deste texto, me evoca Sartre dizendo aos jornalistas, na sua entrevista pelos setenta anos, ser necessário acrescentar o humor, sempre. A propósito de Sartre, mais uma lição de Candido. Vejo agora no Jornal Eletrônico da Unesp ("O dia em que Araraquara foi existencialista"), em 4 de novembro de 1960, que Candido e Fernando Henrique teriam sido os tradutores simultâneos de sua palestra naquela cidade. Mas o Professor, para minha surpresa, me contou que não conversou com Sartre, que não quis ser mais um a sobrecarregar o viajante que certamente o esqueceria no dia seguinte, tantas eram as pessoas que o rodeavam e apesar do intérprete ser o seu amigo próximo, Ruy Coelho.

O exercício da reflexão e a aquisição do saber são duas características básicas do Professor. Era basicamente um pensador, o tempo todo, escrevendo ou conversando, sempre aberto para o novo e para a reformulação, sempre jovem de espírito. Creio que Antonio Candido, sob esSe aspecto, nunca envelheceu. Digo no sentido de aceitar o novo, de querer saber, aprender. Como muitos da sua geração, não aprendeu, e nem quis fazer uso do computador ou do celular, mas isso não o tornava velho.

$\mathrm{O}$ interesse que tinha pela vida, pelas coisas novas era surpreendente, mas não lhe tirava o espírito crítico. Lamentava a 
falta de líderes de peso, nos anos recentes do séc. XXI. Sempre contava que seu dileto discípulo, Roberto Schwarz, dizia que atualmente o mundo só tinha um líder, o Papa Francisco. Mas na juventude de Candido, líderes de peso não faltavam, fossem Charles De Gaulle, Winston Churchill, Mahatma Gandhi, Martin Luther King ou Nelson Mandela, fossem líderes do mal como Adolf Hitler, Joseph Stalin ou Francisco Franco.

A aquisição do saber manifestava-se pela curiosidade pelos filmes novos, pelos trabalhos acadêmicos (ou não) de filhas, genros, neto e netas, ex-alunos, amigos, pela mudança de costumes - muitos dos quais via com muito otimismo, como o feminismo, por exemplo, achando normal os radicalismos até os movimentos se afirmarem. Concordava com os que dizem que estamos em um momento de mudança de paradigmas, muito mais do que mudança de geração, mudanças como as acarretadas há quinhentos anos pelos descobrimentos e a invenção da imprensa ou pela revolução industrial, ocorrida a partir do século XVIII.

Levei-lhe, para sua satisfação e surpresa - como nunca soubera deste filme? - O tempo redescoberto, dirigido pelo chileno Raúl Ruiz, com argumento de Gilles Taurand, a partir da obra de Proust, com Catherine Deneuve (Odete) e John Malkovich (Barão de Charlus), entre outros. Marcel Proust era uma de suas grandes paixões literárias, isso todos sabíamos, algumas edições nas prateleiras de sua sala, e alusões aqui e ali. Declarava-se um "proustiano fanático" (FONSECA; SCHWARZ, 2018, p. 82) mas dedicou-lhe apenas um texto, "Realidade e realismo (via Marcel Proust)", em Recortes (CANDIDO, 1993b).

Dizia que a admiração por Proust e Shakespeare era tanta que se inibia de escrever sobre eles. Assim como eu me inibia de falar com ele sobre sua própria obra, Formação da Literatura 
Brasileira: momentos decisivos, especialmente. E, quando eu o fazia, era para elogiar trechos do texto sobre $\mathbf{O}$ deserto dos tártaros, ou da "Dialética da Malandragem", dois dos meus preferidos, que ele afastava com a mão, subitamente tímido. Como quando lhe perguntei onde lecionara em Paris, nos anos 60 , e ele quase que pedindo desculpas contou que na Sorbonne.

De Shakespeare não entendia nada, era um completo analfabeto, disse a mim e a Adélia, em uma visita que fizemos a ele, para, em seguida nos surpreender, rememorando palestra e texto sobre Ricardo II. "Ainda bem que o senhor não sabe nada", comentamos às risadas, Adélia e eu, mas ele mudou de assunto. (NOVAES, 1992, p. 87).

Diz no texto sobre Ricardo II:

Shakespeare faz do rei e do seu poder um fulcro de relações simbólicas entre o sangue, a seiva, a terra; entre o homem, a planta, a natureza; entre o poder e a vegetação; entre saúde-ordem social e doençadesordem. É através deste vasto relacionamento, dessas intercomunicações, que se configura o problema do mando e da obediência, da transgressão, da culpa, do legítimo e do ilegítimo. (NOVAES, 1992, p. 92).

A legitimidade do poder é uma de suas abordagens. Estivesse vivo, como analisaria a legitimidade dos governantes atuais?

Surpreendeu-me com o quanto gostava e conhecia de cinema. Dizia, em francês e português, as falas de Pierre Fresnay em Monsieur Vincent, diálogos de Jean Anouilh, um dos roteiristas de São Vicente de Paulo (título em português), Oscar de filme estrangeiro de 1948 (levei-lhe esse DVD), santo a quem admirava, como se lê em um discurso de agradecimento por homenagens recebidas por ocasião dos seus 80 anos: 
Tanto no domínio do saber, que é o nosso campo interno, como na da luta político-social, que nos solicita externamente na sociedade maior, deve prevalecer como critério de conduta o ponto de vista atribuído a São Vicente de Paulo, isto é, que nunca fazemos o suficiente por mais que façamos, e por isso é preciso fazer cada vez mais. (AGUIAR, 1999, p. 99).

Dizia que eu lhe propiciara um curso sobre Chopin, ao presenteá-lo com Impromptu, 1991, direção de James Lapine, e Chopin - Desire to love, uma produção polonesa, dirigida por Jerzy Antczak, de 2002. Filmes que corrigem a desinformação de À Noite Sonhamos, de 1945, direção de Charles Vidor. Impromptu, especialmente, embora tratando de um hipotético fim de semana no campo, reunindo Chopin, Sand, Lizt, Musset, Delacroix e outros, nos oferece suas características pessoais tais como nos chegaram através de farta documentação.

Fiz um trabalho para Antonio Candido, como aluno, sobre Le Dieu Caché, de Lucien Goldmann (1959). Ao me devolver, com valiosas observações manuscritas, me surpreendeu perguntando pelos meus contos na gaveta, pois o trabalho tinha enredo. Com o apoio inestimável de Francisco de Assis Barbosa, meu livro dos contos engavetados, O Mar tem várias cores, editado pelas Duas Cidades, teve sua noite de autógrafos em 19 de dezembro de 1979, na Livraria Capitu, à rua Pinheiros.

Alguma alma caridosa, não me lembro quem, depois me contou que Antonio Candido não via no livro nada de extraordinário, mas que a minha paixão pela literatura era tanta que eu merecia o estímulo.

Deu-me uma generosa entrevista para o livro Justiça e Paz - Memórias da Comissão de São Paulo, mas creio que o desagradou a maneira informal como fiz as citações bibliográficas, embora não tenha dito nada, ou por isso mesmo. 
Presenteou-me com muitos livros e duas revisões - com anotações e correções a lápis - do meu romance, ainda hoje sendo escrito, do qual me mandou tirar certas passagens pretensamente eróticas, porque atentavam contra a "profunda humanidade" [sic] dos meus personagens e porque não tenho a mão de D. H. Lawrence. Elogiou minha escrita, muito melhor do que a de um escritor de destaque, e não era Paulo Coelho. Deixou-me feliz e pretensioso.

E poucos como ele, pela simples presença, nos ensinaram a ter uma boa disposição para com o próximo, emoções adequadas e generosidade perante os problemas da vida e as contradições do mundo e dos seres. Conheço poucas pessoas com a capacidade de relacionamento de Antonio Candido. Cultivava as amizades, tinha prazer na conversa, fosse erudita, fosse banal, conversar era com ele mesmo, e comigo também. Talvez a nossa maior afinidade. Evocava com prazer os amigos, falava deles com frequência. O maior deles, insistia, sua mulher, dona Gilda. Foram doze anos de viuvez, sessenta e dois de casamento. A viuvez, uma saudade dolorida, mas vivida, como todo ele, com estoicismo, com discrição. "Perdi meu melhor interlocutor", repetia, "e sei que você me entende".

Não me avisara da morte dela para não atrapalhar o meu Natal. Dona Gilda faleceu em 25 de dezembro de 2005, aos 86 anos. Alzheimer, um dos seus medos, um mistério. Discordava dessas conversas de que ocupar o cérebro previne. Dois cérebros privilegiados, o dela e o de Caio Prado Júnior, anos sem lucidez.

Foi no enterro de Caio Prado, em 1990, ao qual compareci pelo afeto que tinha pelo filho dele, Caio Graco Prado, o jovial editor da Brasiliense, dali a dois anos também mais uma saudade, que o Professor me apresentou a Florestan Fernandes. 
Florestan era um amigo de quem muito falava e admirava. As origens simples, chegara a ser engraxate na rua quando menino, batalhador, autodidata, um dos cérebros mais privilegiados que conhecera. A amizade com Florestan foi das mais gratificantes que teve e rendeu um livro de homenagem ao amigo morto, em cuja quarta capa escreveu Vladimir Sacchetta:

Este livro constitui a memória e o balanço da relação emblemática e fecunda entre Antonio Candido e Florestan Fernandes, companheiros fraternos que abraçaram o socialismo na esperança de que, por meio dos trabalhadores e dos humildes, o Brasil possa superar suas tragédias de exclusão e injustiça social. (CANDIDO, 2001).

Décio de Almeida Prado era como irmão, dizia, "fazíamos parte dos chato-boys da Revista Clima", e ria; todos esses anos de trabalhos conjuntos. "Ao Antonio Carlos, este livro, dedicado a um amigo seu, com o abraço, também amigo, do Décio A. Prado, 1999". O livro é Antonio Candido: pensamento e militância, organizado por Flávio Aguiar, no qual Décio, no estilo impar que o tornou um dos maiores críticos, historiador e professor do teatro brasileiro, escreveu:

Pois é, meu caro Antonio Candido, aqui estamos nós, não 20 anos depois, como em Alexandre Dumas, mas quase 60 anos depois, numa situação um tanto embaraçosa, você como homenageado, eu como homenageante. Mas fique tranquilo, não me excederei.

[...] depois de refazer sua carreira universitária, ajudou-nos, a mim e Paulo Emilio, a construir as nossas, confirmando-nos, todos os três, como legatários para sempre de Clima. Ele não é, portanto, um acontecimento relacionado unicamente com a inteligência e a sensibilidade literária. É também um acontecimento notável no que diz respeito à volição, ${ }^{1}$

1 Impresso "evolução"; Décio corrigiu à mão, com caneta. 
à voluntariedade. Sofre com as imperfeições do mundo e sente agudamente não poder mudar a si mesmo quanto gostaria. Disse-me certa ocasião; "Fico às vezes satisfeito quando me comparo, mas nunca quando me considero". Haverá reminiscências de Nietzsche nesta moral impaciente com os limites da vontade humana, desejosa de obter vitórias antes sobre ela própria do que sobre os outros? [...]

Como palavra final, quero agradecer por me ouvirem e por me darem a oportunidade de falar em público sobre o meu mais velho e querido amigo. Em particular não teria a coragem de tecer-lhe tantos elogios, pensados por quase 60 anos, porém nunca proferidos de viva voz. (AGUIAR, 1999, p. 43).

Amizades sóbrias, contidas, características de uma geração. Mas se Décio nunca o elogiou de viva voz, não precisava; as lágrimas que verteu quando Candido recebeu o título de professor emérito da USP, falavam por si. "É toda uma vida", explicoume. Lágrimas que Candido também chorou ao chegar ao velório dele. Coubera a mim dar-lhe a infausta notícia, que me fora dada, por sua vez, por Vilma Areas, eu e ela orientandos de Décio. No carro de Laura, com dona Gilda, fomos até o crematório da Vila Alpina. Quase não se falou.

Essa insatisfação consigo mesmo, ao se considerar, Antonio Candido explicitou mais de uma vez. Uma delas, divertida para mim, afinal era ateu, foi quando lhe disse que eu finalmente tinha entendido o pecado original. Em Novas Sementes da Contemplação, escreveu Thomas Merton, é o nascer egocentrado.

- "Será que Deus vai me cobrar isto?", surpreendeu-me o Professor.

- "Como? Para com isto, o senhor não tem nada de egocentrado." 
- "Tenho sim, a vida inteira preocupado com a minha carreira, com a minha imagem."

- "Que é isto, Professor? O senhor sempre ajudou e promoveu tanta gente... O senhor é um construtor de pontes, homem do diálogo, que não faz distinção de pessoas, igualitário, sempre na contramão da segregação e da desigualdade."

Não se deu por achado.

Pouco falava sobre as filhas e netos, defensor de suas privacidades, mas falava da mãe, do pai e dos genros, pelos quais tinha grande carinho, mesmo que não fossem mais genros. Da mãe, evocava mais de uma vez o grande chapéu preto no luto pelo marido, com renda a cobrir o rosto, uma visão terrível e extemporânea, uma vez que a viu do outro lado da Praça da República. Convenceu-a a mudar o hábito.

Do pai, homem culto e dono de uma farta biblioteca, assinante de revistas estrangeiras que traziam a atualidade do mundo para as montanhas de Minas, e ele, desde menino, leitor voraz. O pai que saiu na chuva, noite alta, para atender uma prostituta doente do outro lado da rua, gripou-se e morreu. Seu herói, o pai.

Era muito grato aos que o visitavam com regularidade e sempre mencionava Adélia, Roberto Schawrz, Celso Lafer, Davi Arrigucci Júnior e eu, entre outros. Entre estes, meu primo Francisco Roberto Mariutti, filho de Conceição, a tímida que baixava os olhos, doutor em Letras e às voltas com Paulo Emilio e Alexandre Eulálio. Beto foi quem me ligou para dizer sobre outro primo, sobrinho do avô dele, Francisco de Assis Barbosa, imitando o sotaque de Guaratinguetá: “o imortá morreu”. Anos depois, Antonio Candido sugeriu a Cristina Barbosa, filha do Chico Barbosa, acadêmico e biógrafo de Lima Barreto, que 
entrasse em contato comigo; ela andava pesquisando sobre o pai em São Paulo. Ao telefone, marcamos um encontro na porta da Livraria Cultura, no Conjunto Nacional. Eu disse que me identificaria pela minha semelhança com Jô Soares. "Não pode ser", retrucou, “Antonio Candido disse que você é bonito". Mais uma das piadas do Professor. Na porta da livraria, imediatamente a reconheci pela parecença com a prima Biloca, aquele freira que nunca baixou os olhos para Antonio Candido.

Quem riu melhor fui eu pela surpresa dele pela filha ter escrito que ele era feio. Nunca se pensara feio e mesmo que fosse, ela não precisava ter escrito. Ríamos. Orgulhava-se da produção intelectual das filhas, orgulhava-se delas e as amava, muito e igualmente.

Riamos ao lembrar de Alexandre Eulálio, em um jantar concorrido, perguntando ao Professor se as mansões da família, em Cássia, Minas, ainda estavam de pé, meros sobradinhos... Dizia que José Joaquim de Barros Bella, jornalista e procurador da CEF, foi dos alunos mais inteligentes e o mais triste que teve.

Tinha um carinho especial pela UBE - União Brasileira de Escritores, entre outros, por Anna Maria Martins, Fábio Lucas e por Joaquim Maria Botelho, filho de sua querida amiga Ruth Guimarães. Divertia-se em garantir que Ligia Fagundes Telles nasceu em 1921, ao contrário do que dizia e mostrava a sua certidão de nascimento "corrigida". Abriu mão dos direitos autorais de um de seus livros, não me lembro qual, a favor de um escritor doente.

Contava que a década de 1930, uma década de radicalização, levava as pessoas a optarem, o que influiu na vida associativa, da qual: 
[...] a mais importante no meu tempo, foi a Associação Brasileira de Escritores, a ABDE, fundada no Rio de Janeiro, em 1942, com a finalidade ostensiva de reunir os escritores na defesa dos direitos autorais que, naquele tempo, eram massacrados no Brasil. Mas essa associação tinha, em segundo plano, a finalidade de combater o Estado Novo. Ele se estendeu imediatamente a São Paulo e eu participei da primeira reunião preparatória, na qual estavam presentes Mário de Andrade, Oswald Andrade (sic), Sérgio Milliet, Mário da Silva Brito [...]. Na primeira diretoria, Sérgio Milliet foi presidente e eu segundo secretário. Militávamos por meio dessa associação, cujo maior feito foi a realização do Primeiro Congresso Brasileiro de Escritores, na cidade de São Paulo, em janeiro de 1945. [...] Essa ABDE continuou até pouco depois de 1950, quando houve uma cisão entre comunistas e não-comunistas por causa da Guerra Fria. A reunião dos grupos opostos só se deu muito mais tarde, por iniciativa de Paulo Duarte. (CANDIDO, 2001, p. 76).

Assim, surgiu a UBE, que acabou por outorgar o prêmio Juca Pato a Antonio Candido, em 20 de agosto de 2008, na Faculdade de Direito, entregue pelo embaixador Samuel Pinheiro Guimarães, premiado do ano anterior. O presidente da entidade, na época, Levi Bucalem Ferrari (FSP, Ilustrada, 22 de agosto de 2008), declarou-o um especialista por opção e Fábio Konder Comparato lembrou que desde jovem o Professor "comungou" com os ideais da igualdade. Além dos 90 anos, o mote para a premiação foi a publicação de Um Funcionário da Monarquia - Ensaio sobre o Segundo Escalão (CANDIDO, 2007). O Jornal acrescenta que o embaixador destacou que o premiado "recuperou os esquecidos da história oficial". Em entrevista no próprio livro, Candido diz: "O fato é que, apesar dos pesares, não só os restos do patronato estão ai, mas as classes dirigentes continuam de modo geral a reclamar a necessidade de reformas que, no fundo, não querem efetuar" (CANDIDO, 2007, p. 142) 
Outro amigo amado foi José Petronillo de Santa Cruz, um alagoano nascido no mesmo ano que ele, que adotou o nome de frei Benevenuto, na ordem dos pregadores, os dominicanos, fundador da Livraria Duas Cidades, em 1954, editor de livros do casal Mello e Souza e de outros nomes como Adélia Bezerra de Menezes, Marilena Chauí, Robert Schwarz, Boris Schnaiderman, por exemplo. Santa Cruz teve forte ligação com a mãe do Professor, dona Clarisse Tolentino de Mello e Souza, frequentando sua casa antes mesmo de entrar para a vida religiosa. Quando me surpreendi com a fé católica de Laura, a filha do meio do Professor, ela me lembrou da convivência com Santa Cruz. O Professor considerava-o como irmão e o apoiou em diversas situações, inclusive quando ameaçado de despejo a sede da livraria, no famoso endereço à rua Bento Freitas 158 - alugada a ele pelos dominicanos, ordem da qual desligara-se. Morto em julho de 1997, Antonio Candido sepultou-o no mesmo túmulo de sua mãe, dona Clarisse.

E houve essa amizade com os dois Presidentes da República. Fernando Henrique Cardoso foi seu aluno e o substituiu em umas aulas, certa feita, graciosamente, pelo que era grato. Nos seus oitenta anos, o então Presidente FHC parou sua rua, visitando-o, ainda que em caráter particular.

Considerava Luiz Ignácio Lula da Silva um gênio. Foram muitas as conversas, Lula o visitou algumas vezes na rua Eugênio de Lima. Uma vez eleito, não mais se viram ou se comunicaram. Lula era para ele um dos três maiores governantes que o Brasil teve, pela capacidade de inclusão dos mais desfavorecidos. A História o julgará devidamente, dizia. Os outros dois, segundo o Professor, foram Pedro II, em cujo governo alterou-se o modo de produção com a "libertação" dos escravos e Getúlio Vargas, que ele combateu, mas que instituiu a legislação trabalhista. 
E havia as viúvas de seus amigos, a de Ruy Coelho, almoçando com ele a cada mês; dona Maria Amélia Buarque de Hollanda, a simpatia personificada e que encontrei na casa dele. Orôncio Vaz de Arruda faleceu em 1987, deixando dois livros publicados, Memorando (ARRUDA FILHO, 1973) e Andanças (ARRUDA FILHO, 1987), com prefácio de Alexandre Eulálio. Sua viúva, Rachel, passou a telefonar regularmente e quando parou, o Professor preocupou-se. Procurei seu neto, e fiquei sabendo que estava em uma casa de repouso, o que o entristeceu. Estava sempre querendo informações sobre essas casas, como funcionam e seus custos. Avisei-o da missa de Rachel quando ela partiu, mas não quis ir e mandou que o representasse junto a Felipe, o neto.

Antonio Candido encontrou beleza e positividade em quase tudo. Amava a beleza da vida, esperava ter a sorte de Oscar Niemeyer ao mesmo tempo em que queria ir embora antes de dar trabalho às amadas filhas, Marina, Laura e Ana Luiza, ou antes de ficar fora de si. Mas beleza, para ele, era o encontro da Justiça, o reinado da igualdade, a eliminação da fome.

A paixão pela Justiça já se expressa na pesquisa pela vida dos caipiras, pela reforma agrária, pelo seu doutorado em Sociologia que resulta em Os parceiros do Rio Bonito: estudo sobre o caipira paulista e a transformação dos seus meios de vida (CANDIDO, 1964). Atinge seu auge com Formação da Literatura Brasileira: momentos decisivos (CANDIDO, 1959), que o torna um dos defensores do povo do Brasil, um dos mais autorizados pensadores da sociedade brasileira. Auge? Não. Na sequência, uma série de obras-primas, todas elas, que se torna ocioso enumerá-las, mas das quais destaco, para os professores de literatura, O Estudo Analítico do Poema (CANDIDO, 1999) e Na sala de aula: cadernos de análise literária (CANDIDO, 1985). 
Isso tudo sem falar no antológico "Dialética da Malandragem", infelizmente atualíssima análise da dinâmica da sociedade brasileira (1993a) ou Literatura e Sociedade.

Há certas obras em que não faz sentido pesquisar o vínculo social porque ela é pura estrutura verbal. Há outras em que o social é tão presente - como "O cortiço" [de Aluísio Azevedo] - que é impossível analisar a obra sem a carga social. Depois de mais maduro minha conclusão foi muito óbvia: o crítico tem que proceder conforme a natureza de cada obra que ele analisa. Há obras que pedem um método psicológico, eu uso; outras pedem estudo do vocabulário, a classe social do autor; uso. Talvez eu seja aquilo que os marxistas xingam muito que é ser eclético. Talvez eu seja um pouco eclético, confesso. Isso me permite tratar de um número muito variado de obras. (CANDIDO, 2011).

Ainda na mesma entrevista:

O senhor é socialista? Ah, claro, inteiramente. Aliás, eu acho que o socialismo é uma doutrina totalmente triunfante no mundo. E não é paradoxo. O que é o socialismo? É o irmão-gêmeo do capitalismo, nasceram juntos, na revolução industrial. É indescritível o que era a indústria no começo. Os operários ingleses dormiam debaixo da máquina e eram acordados de madrugada com o chicote do contramestre. Isso era a indústria. Aí começou a aparecer o socialismo. Chamo de socialismo todas as tendências que dizem que o homem tem que caminhar para a igualdade e ele é o criador de riquezas e não pode ser explorado. Comunismo, socialismo democrático, anarquismo, solidarismo, cristianismo social, cooperativismo... tudo isso. Esse pessoal começou a lutar, para o operário não ser mais chicoteado, depois para não trabalhar mais que doze horas, depois para não trabalhar mais que dez, oito; para a mulher grávida não ter que trabalhar, para os trabalhadores terem férias, para ter escola para as crianças. Coisas que hoje são banais. 
Esse é o militante de uma vida inteira, embora não se considerasse. O homem que subiu em uma mesa no jardim da faculdade de medicina da USP, para apoiar uma greve. Que insistia em que não tinha vocação para a política, mas que passou a vida lutando por uma democracia socialista.

Em 2008, escrevi "Humano, muito humano" (FESTER, 2008), a propósito dos 90 anos de Antonio Candido. Um gesto seu, em 29 de setembro de 2014, apenas confirmou o modo como encerrei aquele texto. Encontrei-o na porta de igreja de São Domingos, a noite caindo.

"- O que senhor está fazendo aqui?"

“- Vim à missa de sua mãe."

"- E o senhor veio com quem?"

"- Sozinho, vim de táxi."

Ele estava com 96 anos. Fiquei emocionadíssimo. Talvez o maior presente que tenha me dado. $\mathrm{O}$ ateu assistiu à missa, trocou palavras com algumas pessoas e Adélia levou-o para casa em seu carro.

A mesma Adélia que ligou para o meu celular na manhã de 12 de maio de 2017 para me dizer que ele estava morto. Eu estava sendo hospitalizado, por conta de uma erisipela, e achava que não se fica órfão com mais de setenta anos. E, em seis meses, fiquei duas vezes: em dezembro, dom Paulo; agora, Antonio Candido. Deste, eu tive o consolo de não me despedir.

"- Como vai o senhor?"

"-Eu vou mal, eu vou muito mal."

"- O que o senhor tem?"

“- Nada, minha saúde está ótima, já lhe disse que não vou mais a médicos. Estou sempre bem, felizmente, mas ainda acordo, não morro, não quero ficar paralisado numa cama, não 
quero dar trabalho para minhas filhas. Mas vou mal. O mundo, o Brasil, está tudo de cabeça para baixo. Não entendo e não quero entender."

Estava infeliz, o que nele era raro. Foi assim a nossa última conversa, uns quinze dias antes, ao lado da porta rotatória de uma agência bancária. Estava indignado também com a maneira como o banco o tratara, o estava excluindo, forçando o uso de terminais eletrônicos, teria que pedir ajuda à neta. Reclamou ainda das gravações telefônicas, do tempo dispendido para ser mal atendido, da impessoalidade das máquinas.

Encerrei o artigo pelos 90 anos dizendo que Antonio Candido atingiu, na amorosidade, "o mais alto nível de sua própria humanização, pois, afinal, é para o amor que, em última instância, todos nós fomos criados." (FESTER, 2008).

E amar, Professor, nestes dias que correm e dos quais o senhor está livre, é dos atos mais revolucionários.

\section{Referências}

AGUIAR, Flávio (org.). Antonio Candido: Pensamento e Militância. São Paulo: Editora Fundação Perseu Abramo: Humanitas/FFLCH-USP, 1999.

ARRUDA FILHO, Orôncio Vaz de. Memorando. [S. l.: s. n.], 1973. Edição particular.

ARRUDA FILHO, Orôncio Vaz de. Andanças. São Paulo: Livraria Nobel SA, 1987. 
CANDIDO, Antonio. Formação da Literatura Brasileira: momentos decisivos. São PauloÇ Martins, 1959.

CANDIDO, Antonio. Os parceiros do Rio Bonito: estudo sobre o caipira paulista e a transformação dos seus meios de vida. Rio de Janeiro: José Olympio, 1964.

CANDIDO, Antonio. Na sala de aula: cadernos de análise literária. São Paulo: Ática, 1985.

CANDIDO, Antonio. O Discurso e a Cidade. São Paulo: Duas Cidades, 1993a.

CANDIDO, Antonio. Recortes. São Paulo: Companhia das Letras, $1993 b$.

CANDIDO, Antonio. Vários Escritos. 3. ed. rev. e ampl. São Paulo: Duas Cidades, 1995.

CANDIDO, Antonio. O Estudo Analítico do Poema. São Paulo: Humanitas/FFLCH-USP, 1999.

CANDIDO, Antonio. Florestan Fernandes. São Paulo: Editora Fundação Perseu Abramo, 2001.

CANDIDO, Antonio. Textos de Intervenção. Seleção, apresentação e notas de Vinícius Dantas. São Paulo: Duas Cidades; Ed. 34, 2002.

CANDIDO, Antonio. Um Funcionário da Monarquia - Ensaio sobre o Segundo Escalão. 2. ed. rev. pelo autor. Rio de Janeiro: Ouro sobre Azul, 2007.

CANDIDO, Antonio. O Albatroz e Chinês. 2. ed., aument. Rio de Janeiro: Ouro sobre Azul, 2010.

CANDIDO, Antonio. O socialismo é uma doutrina triunfante. [Entrevista cedida a Joana Tavares]. Brasil de Fato, 8 de ago. 2011.

ESCOREL, Ana Luisa. O Pai, a Mãe e a Filha. Rio de Janeiro: Ouro sobre Azul, 2010.

FESTER, A. C. R. . Humano, muito humano: Antonio Candido. O Escritor Revista da UBE, v. 120, p. 12-12, 2008. 
FESTER, Antonio Carlos Ribeiro. Justiça e Paz - Memórias da Comissão de São Paulo. São Paulo: Edições Loyola, 2005.

FONSECA, Maria Augusta; SCHWARZ, Roberto (org.). Antonio Candido 100 Anos. São Paulo: Editora 34, 2018.

GOLDMANN, Lucien. Le Dieu caché. Étude sur la vision tragique das les Pensées de Pascal et dans le théâtre de Racine. Paris: Éditions Gallimard, 1959.

NOVAES, Adauto (org.). Ética. São Paulo: Companhia das Letras: Secretaria Municipal de Cultura, 19 